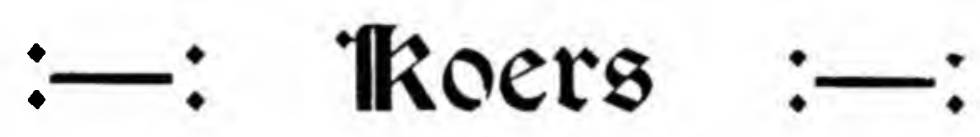

TWEEMAANDELIKSE TYDSKRIF

\begin{tabular}{lll}
\hline \hline DEEL XXI. & APRIL 1954. & No. 5.
\end{tabular}

\title{
DIE CHRISTELIKE UNIVERSITEIT
}

(Intreerede deur prof. dr. J. Chr. Coetzee as Rektor van die Potchefstroomse Universiteit vir Christelike Hoër Onderwys op 19 Februarie 1954).

\section{Historiese Inleiding:}

a. Ek wil in hierdie uiteensetting die woord "Christelik" in sy besondere betekenis gebruik. In sy algemene gebruik is dit heeltemal te vaag vir ' $n$ duidelike skets van die opkoms en ontwikkeling van die idee van 'n Christelike universiteit. Die algemene betekenis van die woord het min of meer net 'n sedelike bepaling. In diê gebruik word hoofsaaklik bedoel sekere ideale van menslike gedrag, soos deug, eerlikheid, geregtigheid, vryheid, verantwoordelikheid, ideale wat wel in noue verband staan met die Christendom maar wat tog bloot humanisties van aard en inhoud en doelstrekking is. Wanneer ek die woord in hierdie uiteensetting gebruik, dan bedoel ek die besondere betekenis. Hierdie betekenis word vir ons bepaal in die Heilige Skrif en in die Christelik historiese tradisie wat saamgevat is in die Christelike geloofsbelydenis en deur die Christelike kerk betuig word in sy formuliere van eenheid, in sy liturgie, in sy ampte en instellings. Vir my doel hou die 
woord „Christelik” dus in die erkenning en aanvaarding van die gesag van Godsopenbaring van Homself in Jesus Christus, die vleesgeworde Woord, van die sondeval van die mens en sy verlossing deur die soenverdienste van sy Saligmaker, van die vertroosting van Gods Heilige Gees en van die Kerk as die bruid vna Christus en as gemeenskap van die heiliges gedra deur die Heilige Gees. Mense wat hulleself Christene in die algemene sin noem, gaan selde verder as die erkenning en aanvaarding van Jesus Christus as die ideale mens vir alle tye, maar die wat Christene in die besondere sin is, erken en aanvaar Hom as die eniggebore Seun van God, as die Redder en Verlosser van die verlore mensdom.

b. So opgevat kan ons met reg beweer dat die universiteit in sy ontstaan en vroeë ontwikkeling 'n Christelike inrigting was, maar dat die universiteit sinds die vorige eeu hier en daar nog net hoogstens in die algemene sin 'n Christelike karakter dra.

Die moderne universiteit vind sy ontstaan omstreeks die twaalfde, dertiende eeu van ons jaartelling. Voor die tyd was daar in die tegniese sin van die woord geen universiteite nie. Die eerste inrigtings wat die naam kon dra, was die inrigtings te Bologna (omstreeks 1158) en te Parys (omstreeks 1180). Hierdie inrigtings is uit die Christelike kerk gebore; alhoewel hulle opgelei het vir die onderwys, die regte, en die medisyne, was die hoofdoel tog die studie van die Teologie en die opleiding van die geestelike stand. Die Teologie was meer as net die koningin van die wetenskappe, dit het feitlik algehele beslag gelê op die studieloopbaan van die jeug. Die oudste universiteite was dus oorspronklik volgens hul belydenis Christelik in die engere sin van die woord. Dit was ook die karakter van die ander universiteite wat in die dertiende, die veertiende en die vyftiende eeu gestig is. Ek noem net die volgende: Oxford (omstreeks 1200), Cambridge (1231), Sorbonne (1385), Keulen (1388), Leipzig (1409), Leuven (1425), Glasgow (1453), Uppsala (1477).

Deur die oorheersende invloed van die Katolieke Kerk het die universiteite deur en deur Christelik gebly tot aan die Reformasie. Die Reformasie self het geen verandering aan die Christelike karakter van die universiteite gebring nie; dit het dit eerder versterk. Die opkomende Renaissance-Humanisme van die vyftiende, sestiende eeu kon nog weinig invloed uitoefen op die Christelike onderwys van die universiteit. Selfs manne soos Desiderius Erasmus was nog belydende Christene; dieselfde geld vir die groot natuurwetenskaplikes, wiskundiges en wysgere van daarde tyd, al begin die vrysinnigheid sy voortekens wys in manne soos Francis Bacon. 
Die oorheersende Christelike karakter van die universiteit bly gehandhaaf dwarsdeur die sestiende en die sewentiende eeu. Dit is waar dat die aantal vrydenkende geleerdes algaande toegeneem het, maar hulle was onder die personeel van die universiteite die uitsonderings en kon aan die karakter daarvan as Christelike inrigtings weinig verander.

c. Die ontkerstening van die universiteit begin in die tweede helfte van die agtiende, en veral in die negentiede eeu neem dit geweldige afmetings aan om in die twintigste feitlik voltooi te word. Maar die voltooiing van die proses van ontkerstening bring in verskillende lande ook weer reaksie van die kant van oortuigde Christene.

Die eeu van die rede en die verligting tas naas die algemene maatskaplike en kerklike lewe veral die universiteite en die hoër onderwys aan. Hierdie aanval rig hom veral teen die Kerk as oorheersende mag en teen die Teologie as die koningin van die wetenskappe. Tot aan die Reformasie het die Kerk en die Teologie die toon ook op die universiteite aangegee. Vanaf die Reformasie begin die invloed van die Kerk af te neem. Sy eerste geweldige aanval moes dit verduur van die wysgere van die rede en verligting van die agtiende eeu en veral van die politieke wysgere van die Rewolusietyd. Aan die begin van die negentiende eeu het die nuwe Staat die ou Kerk feitlik van sy troon gestoot. Gelyktydig het die Teologie van die koningin van die wetenskappe gedaal tot een van die universitêre studies. Die universiteit onder die beheer van die Staat en die Teologie onder invloed van die vrysinnige filosowe en die opkomende ewolusionistiese natuurwetenskaplikes het al meer en meer verwêreldlik. Teenoor die Kerk word nou gestel die liberalistiese gees, en teenoor die Teologie die eksakte, eksperimentele natuurwetenskappe. Die leerstoele aan die universiteite word meer en meer gevul deur ongelowige geleerdes.

Van die oudste universiteite het Oxford en Cambridge die langste daarin geslaag om Christelik te bly. Maar reeds in 1854 het die Britse Parlement die eerste wetgewing aanvaar wat uiteindelik die alleenheerskappy van die kerk van Engeland oor die oudste universiteite sou beëindig en wat deur lede van die Konservatiewe Party toe alreeds bestempel is as die ontkerstening van die ou universiteite. Die stryd vir en teen die ou universiteite het gegaan oor die toepassing van die sg. „religious tests”: voorstanders van die Christelike universiteit wou hulle gehou, die liberaliste wou hulle opgehef sien.

Intussen het daar in Engeland ook ontstaan die sg. moderne universiteit. Die vernaamste van die inrigtings is die Universiteit van Londen, 
gestig 1826. Onder invloed van die rewolusionêre verligte idees was die inrigting van sy ontstaan af ,liberaal", d.w.s. nie-Christelik. Dit het geen religieuse belydenis aanvaar nie. Die opkoms van die moderne universiteit en die toenemende invloed van die Liberalisme het die ou universiteite in gees en rigting ook modern gemaak. Dit moet egter erken word dat die histories Christelike tradisie van ses, sewe eeue nie so maklik gebreek kon word nie.

Ook in die ander Europese kultuurlande het die universiteit al meer en meer 'n liberale gees en rigting aanvaar. In Duitsland het feitlik alle inrigtings hul konfessionele karakter verloor. In Nederland van die negentiende eeu doen dieselfde ontwikkeling hom voor. In die Verenigde State van Amerika voltooi die ontkerstening van die universiteit hom feitlik volslae.

Aan die begin van die twintigste eeu is daar feitlik net een soort universiteit: die liberale.

Twee geestesrigtinge egter het getuig teen die toenemende liberalisme van die universitêre onderwys, nl. die Roomskatolieke en die Calvinistiese.

d. Die opkoms van die Christelike universiteit in die twintigste eeu moet dan gesien word in die lig van die heersende "liberale" universiteit.

Die Christen sien die moderne liberale universiteit as 'n versameling van mense sonder enige gemeenskaplike oortuiging, lewens- en wêreldbeskouing, van mense wat die mees onverbonde spesialismes nastreef en wat hul sg. „neutraliteit" gebruik as 'n verskoning om alle fundamentele en betwisbare vraagstukke te vermy. Die ingrypende vraagstukke van godsdiens en nasionalisme word nie aangedurf nie. Hierdie "neutraliteit" is vir die Christen slegs 'n bedekgehoue eie oortuiging: dit is 'n standpunt van on-Christelikheid en on-nasionalisme. In 'n liberale universiteit sien die Christen nie afwesigheid van oortuiging nie maar 'n verwarrende verskeidenheid van botsende oortuigings, wat alle eenheid van optrede, alle eie karakter onmoontlik maak. Wat A leer, word deur B bestry. Die onvolwasse gees word sonder hoop in die maalstroom gewerp. Ons opkomende geslag groei sonder koers op.

Teoreties verwerp die liberale universiteit dus enige opging om 'n lewensen wêreldbeskouing uit een stuk te onderrig en op te bou. Maar prakties onderrig dit tog wel 'n beskouing oor lewe en wêreld. Oor die grondvrae 
van lewe en bestemming is ,neutraliteit” onmoontlik: om 'n neutrale standpunt in te neem is niks minder as om wel 'n standpunt in te neem nie. Die liberale universiteit wat gebreek het met die Christelike oortuiging, onderrig die wetenskap en 'n lewenskeuse in 'n nie-Christelike, soms selfs 'n antiChristelike gees. Daarom kan en mag die Christelike ouer en geleerde nie tevrede wees met die onderrig gegee aan die liberale universiteit nie. Hulle moet vir die onderrig van die Christelike jeug pleit vir die bestaan van 'n Christelike universiteit. Die Christen wil nie 'n Christelike universiteit vir almal hê nie maar wel een vir die Christelike jeug.

Ons Rooms-katolieke geloofsgenote voel hieroor net soos hul Protestantse geloofsgenote.

In Rooms-katolieke lande was daar deur al die eeue heen dan ook meer standvastigheid in hul universitêre inrigtings. Getuie is bv. die Roomskatolieke Universiteit van Leuwen, België, wat reeds in 1425 as sodanig gestig en tans nog Rooms-katoliek is. Deurgaans is die universiteite in lande waar die Rooms-katolisisme nog 'n oorwegende seggenskap het, Christelik in wese en onderwys. Maar selfs in ander lande het die Roomskatolieke opsetlik geywer vir die stigting van suiwer Rooms-katolieke universiteite. Ek wil die aandag net op twee belangrike stigtings vestig. Die een is die stigting van die Rooms-katolieke universiteit te Nymegen in 1923 in Nederland met sy oorwegende geloofsrigtings, die Protestantse en die Rooms-katolieke en met sy baie liberalistiese rigtings. Die ander is nog belangriker. Dit is die stigting van die "Catholic University of America” in die Verenigde State van Amerika in Washington, D.C., geïnkorporeer in 1887 en deur die Pous erken in 1889. Die Rooms-katolieke geleerde kan hom eenvoudig nie versoen met die altyd meer en meer liberaal wordende openbare Amerikaanse universiteit nie.

Belangriker vir ons eie geskiedenis is gebeurtenisse in Calvinistiese Nederland en die Verenigde State van Amerika. Die Nederlandse openbare universitiet het in die negentiende eeu volslae liberaal en modern geword, met inbegrip van die ou Christelike universiteite (Leiden 1575, Groningen 1614, Utrecht 1639). Die Calvinistiese geleerde kon niks anders doen as om die stryd aan te bind vir die stigting van 'n Christelike universiteit in Nederland nie. Hierdie stryd is bekroon met die stigting van „De Vrije Universiteit" te Amsterdam in 1880. Die Universiteit is vry van staatsbeheer, vry van liberalistiese neutraliteit, vry in die bepaling en uitbouing van sy Christelike oortuiging in die onderrig en beoefening van die 
wetenskap. In die Verenigde State van Amerika het die klein groep Calvinisties-gesinde geleerdes ook daarin geslaag om 'n eie inrigting vir Christelike hoër onderwys op te rig en vir 'n hele driekwart eeu al alleen in stand gehou. Die inrigting het nog nie volle universitêre status nie maar word tog reeds akademies erken as 'n inrigting vir hoër onderwys. Ek bedoel hier die „Calvin College and Seminary” te Grand Rapids, Michigan, gestig in 1876 maar tot volle bloei eers in ons eeu gekom.

e. Ons moet egter op drie ander belangrike ontwikkelings in ons eeu wys.

Die eerste is 'n poging om in die moderne en liberaal-geworde universiteit 'n Christelike kern te vorm. Een van die kragtigste pleidooie hiervoor word gelewer deur sir Walter Moberly van die Universiteit van Oxford. Hy doen dit o.a. in sy uiters belanrgike werk „,The Crisis in the University”. Moberly aanvaar die feit dat die universiteit vandag in sy wese liberaal geword het, maar hy voel tog dat die Christen tans 'n besondere roeping in die moderne universiteit het. As oortuigde Christen wil hy 'n Christelike suurdee plaas in die liberale universiteit. Vir hom ly die liberale universiteit aan die volgende siektes: vermyding van alle grondvrae, 'n valse neutraliteit, versnippering van alle onderrig en ondersoek, ondeurdagte voorveronderstellings, verwaarlosing van sedelike en geestelike faktore, handhawing van 'n onegte wetenskaplike humanisme en van 'n onegte klassieke humanisme. Daarom pleit hy vir 'n terugkeer na die Christelike tradisie, so nie deur die hele inrigting nie dan wel ten minste deur 'n kern van Christene daaraan verbind. Op diê wyse wil hy nie alleen die vaandel van die Christus ophef nie maar vir sover moontlik die universiteit met die Christelike suurdeeg deurtrek. Hy wil dit as't ware weer kersten. Dit kan hy onderneem, meen hy, omdat die Britse kultuur nog positief Christelik is, omdat dit só nie sal bly as Christene stil sit nie, omdat die meerderheid, as hulle die werklike keuse verstaan, nog sal kies vir die Christendom. Hierdie „Christianisering" sal die universiteitsbeleid ingrypend beïnvloed: dit sal die onvervreemde waarde van die persoonlikheid opnuut benadruk, dit sal weer wys op die plek van die sonde, dit sal nuwe hoop gee omdat die Christelike kyk op die lewe gedra word deur die besef van die goddelike voorsienigheid. Vir hom sal die nuwe universiteit verskil van die ouer Christelike nuiversiteit Jeurdat dit ,open and not closed" sal wees-dus in die Engelse sin 'n „vrye" universiteit wees'.

Die tweede ontwikkeling word getipeer deur die standpunt ingeneem in die Nederlandse „Rapport van de Staatscommissie tot Reorganisatie van 
het Hoger Onderwijs". Hierdie kommissie is so „liberaal" as wat 'n mens maar mag dink. Dit gaan van die standpunt van die liberale openbare universiteit uit. By die formulering van die doelstelling en taak van die universiteit sê die kommissie woordelik dit: „Ook de openbare universiteit steunt op een geestelijke grondslag, al is deze van andere aard dan het godsdienstig-dogmatische fundament, waarop de bijzondere instellingen van hoger onderwijs zijn gebouwd." Die kommissie getuig as sy ervaring „dat de universiteit zich in het algemeen te weinig bewust is geweest van deze tot nu toe nooit volledig onder woorden gebrachte grondslag en van haar daaruit voortvloeiende taak in eigen en in ruimere kring." Die grondslag moet uitdruklik geformuleer word. So 'n verklaring ,zal moeten worden verstaan als een appêl tot alle leden van de academische gemeenschap om de hoge roeping der universiteit als een der belangrijkste cultuurcentra getrouw te blijven, echter niet als een credo-dat bij een kerk behoortnóch als een criterium voor universitaire leertucht". Die kommissis wil selfs dat die gedeelte van die grondslag wat deur sy inhoud daarvoor in aanmerking kom, in die wet vasgelê moet word. Die konklusie waartoe ons kom uit die rapport, is dat selfs die moderne liberaaldenkende maar ernstige geleerde voel dat elke universiteit 'n verklaarde geestelike grondslag moet hê. Dit bevestig die Christen se pleidooi vir 'n verklaarde Christelike grondslag vir sy universiteit.

Die derde ontwikkeling waarop ek die aandag moet vestig, kom in die Verenigde State van Amerkia voor.

Ook daar is onder ernstige geleerdes, nou nie juis van Christelike oortuiging nie, 'n diep gevoelde behoefte om meer diepte van grond te gee aan die moderne liberale universiteit. Die belangrikste figuur in die stryd is R. M. Hutchins, President van die Universiteit van Chicago, wat in verskillende werke en veral in sy „The Higher Learning in America" skerp die aandag vestig op die spesialismes in die hoër onderwys van Amerika en oortuigend pleit vir 'n terugkeer na historiese "fundamentals". Ook in die gesaghebbende "Report of the Harvard Committee" oor "General Education in a free Society” en in die pleitende „Education in a divided World” deur J. B. Conant, President van "Harvard College" word dieselfde tema bespreek. Amerikaanse hoër onderwys moet om sy eie redding terugkeer na 'n algemene opvoeding, na vaste grondslae. In die gesaghebbende „Report of the President's Commission on Higher Education” oor „Higher Education for American Democracy” vind ons dieselfde grondtoon van „establishing the goals”.

Om saam te vat, daar is ' $\mathrm{n}$ besliste neiging om by die hoër onderwys 
terug te keer na 'n vaste oortuiging--'n Christelike grondslag, 'n geestelike grondslag, 'n histories humanistiese grondslag. Daar word geroep om 'n grondslag!

f. Ons moet nog 'n kort skets gee van die ontwikkeling van ons eie Christelike hoër onderwys in Suid-Afrika.

Die eerste inrigting vir hoër onderwys is gestig in Kaapland in 1829, nl. die „Zuid-Afrikaansche Athenaeum”, ook bekend as die „South African College", ten tye van die opkomende liberalistiese gees in Suid-Afrika. In 1866 is te Stellenbosch begin met 'n inrigting wat in 1886 geïnkorporeer is as die Victoria-College-suiwer Christelik van karakter. In 1874 is onder invloed van dr. A. Murray 'n Christelike „Woman's College" begin en in 1907 geinkorporeer as die Hugenote-Universiteitskollege. En in 1869 is te Burgersdorp begin met 'n literariese departement van die Teologiese Skool van die Gereformeerde Kerk. In 1855 stig sir George Grey dio Grey-College wat in 1907 die Grey-Universiteitskollege geword het-Christelik van oortuiging en karakter. Die stigting van die Transvaalse Universiteitskollege in 1906 is ietwat minder prinsipieel-Christelik, net soos die stigting van die Natalse Universiteitskollege in 1909 te Pietermaritzburg en van die Rhodes-Universiteitskollege te Grahamstad in 1904. Ons mag met reg beweer dat alle inrigtings vir hoër onderwys wat tussen 1829 en 1909 in Suid-Afrika gestig is, ' $n$ min of meer beslis Christelike karakter gedra het, behalwe miskien in die geval van die Johannesburgse tak van die T.U.K., maar seer seker ook in die geval van die Pretoriase tak daarvan.

Formeel en essensieel kom daar egter in 1916 'n skerp wending in die karakter van die hoër onderwys. Deur Wet No. 12 van 1916 word daar drie universiteite in die lewe geroep: die van Kaapstad en Stellenbosch as aparte inrigtings en die gefedereerde Universiteit van Suid-Afrika met saamstellende kolleges op Wellington, Grahanstad, Bloemfontein, Pietermaritzburg, Pretoria en Johannesburg en sinds 1921 ook op Potchefstroom. In die Wet is daar een uiters gewigtige klousule en wel no. 25, later bekend geword as die ,gewetensklousule”. Die klousule lui so: „Niemand mag op enigerlei wijze aangaande zijn godsdienstige gesindheid getoetst worden als voorwaarde om gegradueerde van de Universiteit, of professor, lector, docent of student van de Universiteit te worden of blijven of om daarin een ambt, emolument of voorrecht te bekleden of te genieten, zullende tevens aan niemand de voorkeur gegeven of een voordeel onthouden worden op grond van zijn godsdienstige gezindheid". Hierdie klousule maak in beginsel elke SuidAfrikaanse universiteit 'n liberale, oftewel 'n neutrale, universiteit. Van 
' $n$ bepaalde en besliste godsdienstige beginsel is daar nou geen sprake meer nie. Dat die meeste van ons bestaande universiteite nog Christelik is, moet eerder histories as prinsipieel gesien en verklaar word. Sowel Engelsas Afrikaanssprekende Suid-Afrika is nog in hul grond Christelik. Maar in beginsel is die Suid-Afrikaanse universiteite dit nie meer nie. Nie-Christene het vrye toegang tot die universitêre leerstoele en leerbanke. Geen persoon mag om sy godsdienstige gesindheid van ons inrigtings vir hoër onderwys geweer word nie.

Toe nou die Literariese Departement van die Teologiese Skool van die Gereformeerde Kerk in Suid-Afrika-na 1904 te Potchefstroom gehuisvesin 1919 van die Teologiese Skool afgeskei is, het 'n volhardende stryd teen klousule 25 van wet No. 12 van 1916 begin. Die afgestigte Literariese Departement is na April 1919 deur die oorspronklike oprigters genoem „Die Potchefstroomse Universiteitskollege vir Kristelike Hoër Onderwys". Met die inkorporasie van die inrigting in 1921 onder die Universiteit van SuidAfrika het dit sy beskrywende naam verloor tengevolge van die gewetensklousule en is bekend geword as die Potchefstroomse Universiteitskollege alleen. In belangrike opsigte het die Private Wet No. 25 van 1921 die eie karakter van die inrigting gehandhaaf maar in beginsel het die inrigting geval onder die Wet van 1916. Die liggaam in beheer van die P.U.K. het egter nie die stryd daarmee as verlore gegee nie. Voortdurend het dit geywer vir die verkryging can die oorspronklike naam. By Private Wet No. 5 van 1933 is die stryd bekroon en kon die inrigting weer word die Potchefstroomse Universiteitskollege vir Christelike Hoêr Onderwys. In praktyk het die inrigting selfs in die tydperk 1912-1933 Christelik gebly. Maar in teorie het dit gefungeer onder die sg. gewetensklousule en kon dit dus nie in die ware sin van die woord en daad 'n Christelike inrigting wees nie. Solank die Universiteit van Suid-Afrika sou bestaan met die Potchefstroomse inrigting as een van sy saamstellende kolleges, was daar in beginsel niks aan die saak te verander nie.

Die geleentheid vir die inrigting het gekom toe die een na die ander saamstelende kolleges (Johannesburg 1922, Pretoria 1930, Natal 1949 en Bloemfontein 1950) selfstandig geword het en die Universiteit van SuidAfrika self opgehou het om voort te bestaan as gefedereerde universiteit in 1951. Die Potchefstroomse inrigting sou verhef word tot 'n selfstandige universiteit met sy eie Private Wet. In Maart 1951 het die inrigting nie net formeel nie maar ook wetlik geword die eerste universitêre inrigting wat inderdaad volgens sy Wet 'n Christelike universiteit mag heet. In Artikel 
31 van sy eie Wet verkry dit die reg van owerheidsweë om by die benoeming van sy personeel sorg te dra vir die histories-Christelike karakter. Doserende, navorsende en administratiewe personeel sal as Christene gekeur en benoem word. Die personeel is dus gesluit vir andere: net Christene mag daarop dien. Vir die studente geld 'n ander reël: niemand mag om sy godsdienstige gesindheid belet word om student te word of te bly of ' $n$ voorreg daarin te geniet nie. Die Potchefstroomse Universiteit vir Christelike Hoër Onderwys is dus 'n belydende inrigting; wat sy personeel betref: geslote, maar wat sy studente betref: ope. Ons mag dus met reg sê dat hierdie inrigting 'n openbare inrigting vir Christelike hoër onderwys is.

\section{Die Wese van 'n Chrisgelike Universiteit:}

a. Die Universiteit is geen skool in die gewone sin van die woord nie. Dit moet dan ook duidelik onderskei word van die sg. hoër en middelbare skool. Die taak van 'n skool is eenvoudig om die kind deur onderrig in te lei in die eerste beginsels van kennis en kundigheid. Die hoofdoel van die skool is onderrig. Die laerskool is heel in die besonder toegespits op die onderrig van die feite van ons kennis en van die elemente van ons kundigheid. Daarom karakteriseer ons die laer onderwys as suiwer empiries van aard. Die middelbare skool bou op die empiriese onderrig van die laerskool voort maar voer een belangrike element in. Dit is nou nie langer hoofdoel om die kennis van die kind te verryk en uit te brei en om hom die eerste skrede op die weg van die vaardigheid te laat doen nie. Van die empiriese word nou oorgegaan tot die genetiese. Die feitekennis van die laerskool word op die middelbare skool nog wel uitgebrei, maar die hoofdoel word nou om orde en sisteem en selfs koers daarin te vind. Die samehang van die kennis word nou hoofsaak. Daarom sê ons dan ook dat die middelbare skool die kind begin inlei in die eerste tegniek van die wetdnskap. Die kind ontvang nog hoofsaaklik die onderrig; van 'n eie bydrae tot ons kennis is daar nog nie sprake nie. Die voor-universitêre skool is dus wesentlik 'n inrigting vir die onderrig van die elemente van ons kennis en kundigheid; dit wil die dinge versamel, meedeel en aanvanklik orden en inrig. Die universiteit daarenteen stel dit nie langer as sy hoofdoel nie. Aan die universiteit word nog wel onderrig in kennis gegee, aandag word nog wel gegee aan die vasstelling van die samehang van ons kennis, die wetenskap as sodanig word nog onderrig. Maar die hoofsaak het tog wel essensieel verander. Wat nou hoofsaak word, is die samehang en eenheid van ons kennis. Die kennis van die jongmens word nog uitgebrei; orde en sisteem word nog nagestreef: maar dit alles het geen betekenis meer as die wetenskap nie nou ook verstaan word nie. Daarom karakteriseer ons die arbeid van 
die universiteit as filosofies in die breë sin van die woord. Ons soek hier na die sin en betekenis van ons kennis van lewe en wêreld. Universitêre onderwys word dus prinsipieel bepaal deur ons lewens- en wêreldbeskouing. 'n Universiteit wat in sy arbeid net empiries en geneties bly, bly slegs 'n verheerlikte skool van die middelbare aard. Die jeug kom na die universiteit in die laaste instansie vir 'n gefundeerde en wetenskaplik geformuleerde insig in lewe en wêreld.

Die universiteit is ook geen professionele skool of inrigting nie. Daarmee wil ek nie sê dat die universiteit nie 'n aandeel het aan die professionele vorming en opleiding van die jeug nie. Dit het nog altyd en dit sal nog altyd deel neem aan die professionele opleiding, maar om 'n opleidingskool te wees watter beroep ook al is nie die wesentlike kenmerk van die universiteit nie. Al lei die universiteit vandag op vir die onderwys, vir die handel, vir die medisyne, vir die regte, is dit tog veel meer, veel anders as 'n onderwysersopleidingskool, 'n handelskool, 'n mediese skool, 'n regskool.

Die universiteit is ook geen navorsingsinstituut nie. Dat navorsing .n essensiële deel van die taak van die universiteit is, spreek vanself. Die universiteit dra nie net kennis en wetenskap oor die, dit moet self die wetenskap beoefen, d.w.s. ons kennis uitbou. 'n Hoogleraar wat net onderrig, verwaarloos 'n essensiële deel van sy taak; hy moet ook die wetenskap selfstandig beoefen, self ' $n$ eie bydrae lewer tot die groei en ontwikkeling van die wetenskap.

Die universiteit is ' $n$ inrigting van geleerdheid. Dit wy hom aan die onderrig van die wetenskap en aan die selfstandige beoefening daarvan. Dit is 'n gemeenskap van hooglerare en studente en oud-studente, wat dit in sy wetenskaplike en vormende arbeid dien. Dit word in die eerste plek gekenmerk as die studium generale, as 'n plek waar die sewe vrye kunste en die hoër vakwetenskappe bestudeer en beoefen word. Daarom kan dit nie ' $n$ inrigting van elementêre of sekondêre onderwys wees nie; daarom kan die onderrig nie meer bloot empiries en geneties wees nie; daarom kan dit ook nie algemeen en verpligtend gestel word nie. Uiteraard is dit 'n inrigting vir die tertiêre onderwys, is sy onderrig filosofies van aard, is dit bedoel alleen vir die uitgesoektes, die meer begaafdes.

b. Die universiteit is dus na sy ware wese ' $n$ inrigting vir die samehang en eenheid van ons kennis van lewe en wêreld. In die beste sin van die woord is die universiteit 'n inrigting vir die filosofie. 
Belangriker as die oordraging van die kennis, selfs belangriker as die uitbouing daarvan, is die verstaan, die samehang en eenheid daarvan. Sy hooftaak is dus die vorming en ontwikkeling van 'n eie, selfstandige lewensen wêreldbeskouing. Dit moet meer wees as 'n blote opgaardam van geleerdheid of die voorpos van wetenskaplike ontwikkeling of die opleidingsplek vir toekomstige leierskap. Dit moet die brandpunt vir die bestudering en oplossing van die grondvraagstukke van lewe en wêreld wees.

Ons kan die saak ook so stel: die universiteit moet sisteem, organisasie, insig, eenheid in ons kennis van lewe en wêreld bring. Hierdie eenheid kom alleen deur die filosofie. Dit is die filosofie in die wetenskap wat vir die student die sin van lewe en wêreld laat verstaan, wat sy kennis met die waarheid verbind, wat vir hom sy plek in die wêreld aanwys, wat die grondslae van sy karakter lê, wat aan hom die grondbeginsels vir sy lewenskeuse openbaar, wat vir hom die vorme van sy lewenswandel vaslê.

As dit die wese van die universiteit is-en daar is min denkers wat dit nie aanvaar nie-, dan beklee die universiteit die middelpunt in 'n kultuurvolk se lewe, want uit die universiteit kom die aanstaande volksleiers. En dit lê 'n baie groot verantwoordelikheid in die hande van die hooglerare. En die groot verantwoordelikheid is die leiding van die student op die weg van die vorming en ontwikkeling van 'n eie lewens- en wêreldbeskouing.

Nou kan 'n mens iemand anders nie lei nie, as jyself geen eie, vaste, gesistematiseerde en gefundeerde lewens- en wêreldbeskouing besit nie. Die jong student kom na die universitiet nie net om te hoor wat die hoogleraar weet nie, maar veral om te verneem wat hy dink oor al die grondprobleme van lewe en wêreld. Nou is daar mense wat sê dat die hoogleraar oor sy diepste oortuigings moet swyg, want deur sy gesag kan daar indoktrinasie van sienswyses plaasvind, en teen indoktrinering van die student voel hulle sterk beswaar. Die student, so word beweer, moet vir homself leer dink. Maar mense wat so praat, kan die mens en sy opvoeding nie. Die student wil weet wat sy hoogleraar dink; hy is geregtig daarop om dit te verneem; dit is 'n essensiële deel van sy vorming en ontwikkeling. Die student kan tog nie as onrype mens uit homself tot 'n eie lewenskeuse kom nie-ook hierin moet hy opgevoed word. En die beste opvoeding wat hy hierin kan ontvang, is die voorbeeld van sy leermeester se worsteling met die lewensprobleme. Die hoogleraar moet sy oordeel en bevinding uitspreek as iemand wat daaroor ernstig en lank gedink het. Hy is geen propagandis nie maar'n beskeie en tog besliste denker. Die ware leermeester 
vorm 'n voorbeeld van hoe 'n mens 'n eie, vaste, gesistematiseerde en gefundeerde filosofie kan opbou. Die ware leermeester dring sy opinies nie aan die student op nie, maar hy stel hulle as 'n voorbeeld van ootmoed en van rypheid. Dat die student 'n deel van sy filosofie selfs varwerp, sal hom nooit bedroef nie-hy wil hê dat die student met sy hulp vir hom 'n eie filosofie bou. Wat hom wel die grootste verdriet sal en moet gee, is dat sy student geen eie beskouing ontwikkel nie.

Nou is daar by die uitlewing van die ware wese van die universiteit tog wel sekere essensiële grondvereistes. Ek wil hulle nie volledig hier stel nie maar hulle net formuleer met die oog op die formulering van die wese van die Christelike universiteit. Omdat universitêre onderwys in sy wese filosofies is en moet wees, moet die hoogleraar hierdie grondvereistes kan en handhaaf.

Alle goeie hoër onderwys berus op die vereiste dat leraar en student intens en intelligent belang sal stel in die vraagstukke van lewe en wêreld. Sonder hierdie intelligente drang en entoesiasme moet 'n deurdringing na die probleme van lewe en wêreld misluk en sal daar net 'n oppervlakkige kennismaking ontstaan. Aanvaar moet word dat dinge van die gees belangriker is as stoflike dinge en dat dit 'n lewenstaak word om die geestelike dinge na te speur. Voorwaarde vir ware universitêre arbeid is intellektuele deeglikheid en grondigheid en betroubaarheid. Alle gegewens, en heel in die besonder empiriese gegewens, moet in alle eerlikheidm, nederigheid, nougesetheid benader word. 'n Geleerde wat sy oë sluit vir bewese feite, is geen geleerde nie, geen watenskaplike regter nie, hoogstens 'n blinde pleitbesorger. Alle kontensieuse dinge in die beoefening van die wetenskap moet so benader word: onpartydig maar eerlik soos die goeie regter, wat na hy albei kante gestel het, sy eie mening en bevinding en aanbeveling uitspreek. Daarom moet reg en billikheid altyd die deurslag gee. Die hoogleraar moet verder ook die sedelike moed hê en openbaar om sy diepste oortuigings gegrond op betroubare en geldige gegewens uit te spreek. Dit bring mee dat hy die vryheid van denke en spraak gegun moet word, waarvan hy egter nie misbruik mag maak nie. Want een van die belangrikste grondvereistes vir die ware hoër onderwys, is die groot sosiale verantwoordelikheid van die hoogleraar en die student. Na die universiteit as die inrigting van die hoogste geleerdheid word dan ook tereg opgesien deur land en volk, en die universitiet moet hierdie vertroue waardig bly. Daarom moet die universiteit in sy werksaamhede kan onderskei tussen sin en onsin en moet sy studente die ware sin van dinge leer verstaan en waardeer. 
c. Die hooftaak van die universiteit lê dus in die interpretasie van ons kennis en wetenskap. Die ware wese van die universiteit is dus filosoffes van aard. Hierin lê die bestaansreg van die Christelike universiteit. Die Christelike universiteit is dus anders: 'n universitêre inrigting met 'n Christelike interpretasie van ons kennis en wetenskap, met 'n Christelike filosofie van die wetenskap.

Die vraag wat ons nou kortliks maar prinsipieel moet ondersoek en beantwoord, is die vraag na die betekenis van die taakformulering, nl. 'n Christelike filosofie van die wetenskap.

b

Die Christelike universiteit het as eerste roeping om 'n getuie te wees van die mens se hoogste roeping op die aarde, nl. om God te ken, lief te hê en te dien, en om een lewensdoel te hê: te lewe tot eer van God. Die Christelike universiteit is teosentries in sy arbeid. By die onderrig en die beoefening van die wetenskap word nie die eer van die mens self gesoek nie maar alleen die eer van God, die Skepper van hemel en aarde.

Die Christelike universiteit moet in die tweede plek kom tot 'n Christelike antropologie of mensbeskouing. 'n Universiteit wat die mens sien as die kroon van Gods skepping, as die beeld en gelykenis van God die Skepper, as die in sonde gevalle beeld en gelykenis nie, kan nie 'n Christelike inrigting wees nie. Die Christelike antropologie verwerp dus in beginsel die evolusiegedagte en handhaaf prinsipieel die skeppingsidee. Met die ontwikkeling van 'n Christelike antropologie gaan innig gepaard 'n Christelike psigologie met sy hoofklem op 'n Christelike personalisme. Maar omdat God die mens as man en vrou geskape het en uit hulle die menslike geslag laat gebore word, is net so essensieel die ontwikkeling van 'n Christelike sosialisme met sy hoofklem op 'n Christelike gemeenskap, in die besonder op 'n Christeelike gemeenskap van die heiliges.

Die Christelike universiteit word in die derde plek gekenmerk deur die ontwikkeling van 'n Christelike etiek. Die onderlinge verhouding tussen mens en mens moet gesien word in die lig van die tweede tafel van Gods wet. Op 'n universiteit waar die Christelike sedenorme nie geld nie, kan geen Christelike opvoeding gegee word nie. Op 'n Christelike universiteit geld alleen die Christelike moraal.

Omdat die Christen die mens sien as 'n redelik sedelike wese, geld as vierde eis vir die Christelike universiteit die formulering van 'n Christelike logika. Dit wat die mens in essense onderskei van ander lewende wesens, 
is juis sy rede en verstand. Die juiste plek van die rede en verstand moet bepaal word. Vir die Christelike beoefening van die wetenskap is juis so fundamenteel helderheid oor die toepassing van die denkwette. Die metode van wetenskapsbeoefening is vir die Christen bepaal deur die mens se gawe tot redenering. Die nie-Christelike wetenskaplike laat alle klem val op die mens se gawe tot sistematiese waarneming. Daarom lê hy so baie, selfs uitsluitlike, nadruk op die metode van die sistematiese waarneming by die beoefening van die wetenskap. Die Christelike wetenskaplike ontken nie die plek en reg van die waarneming nie, maar hy sien dit tog maar as die uitgangspunt, die grondslag van sistematiese deurdenking. Die Christelike logicus ken sowel waarneming as deurdenking; hy ken die gawe van waarneming maar ook van denke. Die wetenskaplike moet hom oefen in die juiste waarneming maar ook in die juiste denke. Maar die Christelike wetenskaplike aanvaar naas diê eis die feit dat albei die gawes van waarneming en deurdenking in die sondeval inbegryp is. Die sondige mens neem waar en dink oor die skepping alleen as in 'n spieël: van volmaaktheid in sy waarneming en denke is daar geen sprake nie, albei is verduister deur die sonde. Van ' $n$ volmaakte, absoluut betroubare metode van ondersoek van die skepping is daar dus geen sprake nie. Die waarheid kan alleen by benadering geken word. Daarom is die Christelike geleerde 'n man van die diepste ootmoed. Hy ken maar net ten dele.

Die Christelike universiteit word in die vyfde plek geroepe om by die bestudering van die afsonderlike velde van ondresoek, by die beoefening van die aparte, selfstandige akademiese vakke die Christelike kriteria toe te pas. Vir die Christelike geleerde is die verskillende velde van ondersoek, soos saamgevat in die afsonderlike vakwetenskappe, niks anders as soveel sye van die geopenbaarde waarheid in die skepping of natuur nie. Hy sien die vakwetenskappe as gesistematiseerde, afgebakende, betroubare, geldige kennis van die verskillende openbaringsye van die skepping. Alles wat hy bestudeer, vorm maar net 'n deel van die openbaring van God in die natuur. Daarom bestudeer hy die vakwetenskappe in die lig van Gods woord. Die natuur kan vir hom nie geken en verstaan word sonder die Skriftuur nie. Daarom soek hy om die plek in 'n Christelike speculum mentis vas te stel van die kennis wat gegee en gevind word in alle vakwetenskappe.

Die Christelike universiteit word in die sesde plek bepaal deur die hoë besef aangaande die sin en betekenis van die Christelike roeping. Die Christelike geleerde aanvaar die feit dat God die mens op aarde geplaas het en aan hom 'n bepaalde roeping gegee het. Al het God aan die mens as mens die roeping 
gestel om die aarde te onderwerp en om te heers oor die visse van die see en die voëls van die hemel en oor al die diere wat op die aarde kruip, gee Hy aan elke mens sy bepaalde talente en gawes en daarmee 'n eie roeping. Die werk wat die mens op aarde doen, is 'n werk deur God aan hom opgedra. Omdat die Christen so 'n hoë waarde heg aan die roeping, is alle arbeid van watter aard ook al roeping. Hy moet dit vervul soos God dit van hom eis: alles moet geskied tot eer van God, en elke arbeider sal aan God rekenskap moet gee van sy rentmeesterskap. Selfs sy werk is nie sy eiendom nie; dit is 'n gawe van God. Daarom ken die Christen geen hoë en ook geen lae beroepe nie: alles kom van God. Maar elke werker moet dan aan God, sy medemens en homself rekenskap gee van sy beoefening van die roeping. Heel in die besonder geld dit vir die geleerde: dit is God wat hom tot die taak roep en aan God moet hy rekenskap van sy wetenskapsbeoefening gee. Daar is geen wetenskap bo die ander wetenskappe nie; elkeen weerspieël maar net een aspek van die verskeidenheid van die natuurlike openbaring. Die Christelike universiteit moet die sin en inhoud van die Christelike roeping leer ken en vat-vir elke mens, hetsy hy letterkundige, geskiedkundige, sielkundige, sosioloog, ekonoom, wiskundige, skeikundige of wat ook al mag wees. Daar is geen veld van wetenskapsbeoefening wat buite die roepingsbewustheid van die Christelike geleerde val nie.

Die universiteit wat homself aanmeld as Christelik, moet verder homself rekenskap gee van die Christelike politica. Die probleme van die reg, sy formulering, sy handhawing en uitvoering moet deurdink word in die lig van die geopenbaarde Waarheid. Vir die organisasie en administrasie van die universiteit is dit van beslissende betekenis of daar 'n Christelike of nieChristelike regsleer geld. Hierdie beginsels geld net so sterk vir die onderrig en die tug op die universiteit.

Een belangrike terrein waarop die Christelike universiteit tot helderheid moet kom, is die van die metafisika. Die Christelike geleerde het 'n Christelike wêreldbeskouing. Sy onderrig en wetenskapsboeefening word bepaal deur sy wêreldbeeld. Op die vrae of die ware werklikheid natuurlik of/en bonatuurlik, enkelvoudig of/en meervoudig, stoflik of/en geestelik, tydelik of en tydeloos, ruimtelik of/en ruimteloos, ordelik of /en ordeloos is, moet hy die antoowrd van 'n Christelike geleerde kan gee.

Ten slotte is daar een belangrike vorm van die opvoeding wat in die wese van die Christelike universiteit opgesluit lê. Die Christelike universiteit moet vir sy werk 'n betroubare en geldige beskouing formuleer oor die 
doel, plek en inhoud van die godsdienstige opvoeding. In ons eeu is dit soveel te dringender. Daar was 'n tyd toe die Teologie en die godsdienstige opvoeding hoofdoel en hoofinhoud van die universiteit se taak was. Daar was 'n tyd toe die Teologie die koningin van die wetenskappe en godsdiens die sentrale vak op die universiteit was. Maar daar het ook 'n tyd gekom toe die Teologie gelykgestel is aan ander wetenskappe en dus maar net een van die vakwetenskappe geword het, en die godsdiensonderwys net tot ' $\mathrm{n}$ halfuur of minder beperk is-'n godsdiensonderwys op homself, sonder enige verband met die ander onderwys. En daar is nou die tyd dat Teologie en godsdiensonderwys selfs geen plek meer vind in die moderne universiteit nie. Die Christelike universiteit het 'n dure roeping ten opsigte van die Teologie as vakwetenskap en van die godsdiensonderwys as sodanig.

\section{Die Funksies van 'n Christelike Universiteit:}

a. Vir sover daar sprake is van hoër onderwys ten tye van die hoogtepunt in die Griekse kultuurlewe, was die vernaamste funksie daarvan die vorming van die goeie burger. Deug by die individu en geregtigheid by staat kan beskou word as die Griekse ideaal van die funksie van die hoër onderwys. Met die opkoms van die universiteite as sodanig gedurende die twaalfde en die dertiende eeu na Christus is hierdie ideaal gehandhaaf veral ten opsigte van die sg. artes liberales maar uitgebrei ten opsigte van die invoering van die scientiae-Teologie, Medisyne, Regte-as die nagraadse spesialisering vir die drie beroepe. Die hooffunksie het dus gebly die vorming van die uitgesoektes wat toekomstige leiers in die kultuurlewe sou word. Maar die vorming was in geen sin tegnies of professioneel nie; dit was nie veel meer as ' $n$ inleiding van die uitgesoektes in hul kultuurerfenis. Dit was die ideaal van 'n liberale opvoeding: 'n opvoeding van die vrye man nie as dienskneg nie meer as leier, 'n opvoeding wat algemeen-kultureel was en nie tegnies gespesialiseerd nie, 'n opvoeding wat gesoek het na die sistematisering en interpretasie van kennis eerder as na die versameling en ophoping van kennis, 'n opvoeding wat gekenmerk word deur die intieme intellektuele omgang tussen hoogleraar en student.

Met die herlewing van die Klassieke en die opkoms van die Renaissancehumanistiese gees, kom daar algaande 'n veranderde beskouing oor die funksie van die universiteit. Dit vorm die begin van die moderne universiteit en langsamerhand word die Christelike liberalisme vervang deur positiwistiese liberalisme wat hom veral sinds die aanvang van die negentiende eeu al sterker laat geld het. Met die opkoms van die moderne intellektualisme en scientialisme word die hoofnadruk verskuif van onderrig na eie ondersoek en 
navorsing, die bevordering van die wetenskap eerder as die oordrag van kennis word dié funksie van die universiteit. Met hierdie verskuiwing van die aksent kom daar ook ander sake na vore: geleerdheid om die geleerdheid word die eintlike taak van die universiteit; deurdat die universiteit langsamerhand 'n gemeenskap van blote geleerdheid en wetenskap word, word dit algaande losgemaak eers van die Kerk en later ook van die Staat; om sy werklike funksie uit te oefen word al meer en meer gepleit vir akademiese vryheid van die hoogleraar, heel in die besonder'n vryheid los van alle voorveronderstellings; alle arbeid op die universiteit moet vry, voorlopig van aard en nie gesaghebbend wees nie; daarom moet die geesteshouding van die universiteitsmens een van afsydigheid en van objektiwiteit wees, hy moet nie tussen die dinge staan nie maar daarbo; en daarom moet alle arbeid van 'n baie hoogstaande aard wees, alle middelmatigheid moet vermy word, daar moet krities gestaan word teenoor vakke en metodes; en ten slotte moet die universiteit in die wydste sin van die woord speling aan alle geestesrigtings gee, van 'n geestelike grondslag mag daar geen sprake wees nie, beginselloosheid, neutraliteit word die ideaal.

Die humanistiese liberalisme moes self aan die begin van die twintigste eeu plek maak vir ' $n$ nuwe gees en idee in die universitêre onderwys. Die twee grondfaktore vir die nuwe gees is die geweldige ontwikkeling van die moderne toegepaste wetenskap en tegnologie en die toenemende demokratisering van die universiteite. Die nuwe gees bring weereens 'n verskuiwing van die aksent op die primêre funksie van die universiteit. Die ontwikkeling van die toegepaste wetenskap en die tegnologie bring 'n verandering in die stof en die metode van die universiteit en dus ook in sy doelstelling. Die toegepaste en tegniese wetenskappe neem al meer en meer die kurrikulum in beslag en eis as hooffunksie van die universiteit die professioneel-tegniese opleiding van die studente. Die hoofdoel word dus prakties, selfs utilisties: die wetenskap moet beoefen word vir die bevrediging van die mens se behoeftes; tegniek en later tegnologie neem die plek in van die akademiese wetenskap. Maar die verandering spreek nog duideliker uit die moderne metode: waarneming en proefneming vervang byna heeltemal deurdenking; analise verdring sintese, induksie deduksie as grondmetode van wetenskaplike ondersoek; dinge wat nie empiries en analities ondeersoek kan word nie, word so nie verwerp nie dan tog wel geminag. Ewe belangrik is die invloed van die toenemende demokratisering van die universiteit. Die universiteit is nie langer ' $n$ uitgesoekte gemeenskap van geleerdes en begaafdes nie maar dit word ' $n$ ope gemeenskap vir almal. Die toestroming van die groot massas bring mee 'n minder akademiese kurrikulum, 'n verlaging 
van die suiwer akademiese standaarde, ' $n$ vervanging van die suiwer liberale doelstelling deur 'n meer utilistiese doelstelling.

Maar ernstige denkers begin al meer en meer insien dat die jongste ontwikkeling op die gebied van die funksie van die universiteit enitlik 'n krisis in die hoër onderwys veroorsaak het. Van ortodoks Christelike, van vrysinnig Christelike, van volslae vrysinnige kant word daarop gewys. Ek mag ter stawing net wys op die vrysinnige ontwikkeling in Amerika onder invloed van R. M. Hutchins wat die universitêre lewe wil terugroep na ,fundamentals" en na 'n ,general education" en van Carmichael se belangrike studie oor die veranderende rol van die hoër onderwys. Carmichael is verteenwoordiger van 'n sterk vrysinnige rigting, verskillend van die van Hutchins. Hy voer 'n nuwe idee in: Die universiteit mag nie langer net ,a reservoir of learning, the outpost of scientific advance or a training station for future leaders" weees nie. Sy hooffunksie word nou die daadwerklike ingryping in die oplossing van die fundamentele menslike probleme: dit moet ,a catalytic agent" word. Ele sosiale, ekonomiese en politieke probleem vorm 'n deel van sy funksie. Die universiteit mag geen ivoortoring wees nie: dit moet afdaal na die openbare mark van die lewe. Die belangrikste kriterium by die bepaling van die universiteit se taak is ,the idea of relevance" en vereis 'n herwaardering van die sosiale funksie van die universiteit. Van ortodoks Christelike kant is van besondere belang die bespreking van „The Crisis in the University" deur sir Walter Moberly. Skerp trek hy te velde teen die moderne universiteit, teen sy doel, inhoud en metode, maar hy aanvaar tog die feit dat 'n Christelike universiteit nie die ideaal is nie maar slegs die vorming van 'n Christelike kern of suurdeeg in die moderne universiteit. Besonder belangrik-om nie meer te noem nie-is die „Rapport van de Staatscommissie tot Reorganisatie van het Hoger Onderwijs" (Nederland). In hierdie rapport vind ons een van die waardevolste formulerings van die taak en funksie van die midde-twintigste eeuse universiteit. Dit verwerp die moderne taakstelling omdat dit nóg aan die opvoedende taak van die universiteit nóg aan die ontwikkeling van die wetenskap as sodanig plek inruim. Die Staatscommissie roep die universiteite terug na die formulering en uitlewing van 'n eie geestelike grondslag. Op grond van sy eis tot formulering en uitlewing van die geestelike grondslag, kom die kommissie tot die volgende doelstelling: „Hoger onderwijs wordt gegeven aan universiteiten en hogescholen. Deze bedoelen de ontwikkeling der wetenschap, alsmede de vorming en voorbereiding tot zelfstandige beoefening der wetenschappen en tot het bekleden van maatschappelijke betrekkingen, waarvoor een wetenschappelijke opleiding vereiste is of dienstig 
kan zijn. Tevens hebben de openbare universiteiten en hogescholen tot doel het bevorderen van de geestelijke en zedelijke vorming en het maatschappelijk verantwoordelijkheidsbesef der studentern, een en ander in verband met die geestelijke waarden, die ons volk in de loop zijner historie hebben gekenmerkt, door Christendom en Humanisme zijn bepaald en in het bijzonder tot uiting komen in de eerbiediging van de medemens". Hier is dus sprake van 'n vierderlei funksie: die ontwikkeling van die wetenskap, vorming en opleiding tot wetenskapsbeoefening, vorming en opleiding vir maatskaplike betrekkinge, die geestelike en sedelike vorming van die studente.

Hiermee kan ons nou oorgaan tot die formulering van die funksies van 'n Christelike universiteit.

b. Die Christelike universiteit is dan 'n inrigting vir Christelike hoër onderwys. Dit het 'n geestelike beginsel wat suiwer Christelik gelowig van aard is. Hierdie beginsel is die Christelike lewens- en wêreldbeskouing soos opgebou en ontwikkel uit die geopenbaarde waarheid en dus in die lig van Gods Woord soos vervat in die Heilige Skrif. Die Christelike universiteit is, om dit so uit te druk, dan die intellektuele kragstasie vir die gelowige gemeenskap: 'n plek van Christelike geleerdheid, 'n voorpos of brandwag vir die uitbouing van die Christelike wetenskap, 'n kweekskool van die toekomstige Christelike volksleiers op allerlei terreine van die lewe.

Die Christelike universiteit het in die eerste plek dieselfde funksies as enige ander soort universiteit en in die tweede plek sy eie interpretasie van die universiteit se funksies en taak in die samelewing.

As eerste funksie moet ons stel die onderrig van al die verskillende wetenskappe-die volle artes liberales en al die scientiae. Dit is ' $n$ inrigting vir Christelike onderwys in die wetenskap. Al het die jongmens as kind en rypende jeug al heelwat kennis op die laer- en middelbare skool opgedoen, bly dit nog nodig dat die inrigting vir hoër onderwys hierdie kennis sal aanvul, uitbrei, verder orden, rangskik en sistematiseer. Maar hierdie onderrig geskied in die lig van die Christelike beginsel en op die Christelike gronsdalg. Die onderrig geskied in alle opregtheid, alle ootmoed, alle erkenning van die verduistering van die menslike verstand, as middel en weg tot die kennis van die algemene en besondere openbaring, in Heilige Skriftuur en in natuur vir die menslike verstand blootgelê.

As tweede funksie volg die ontwikkeling van die wetenskap deur eie selfstandige ondersoek en navorsing. Die som van die wetenskrap raak 
nooit ten einde nie, want die menslike verstand bly duister, en dit is alleen deur harde en volhardende inspanning dat die geleerde al nader en nader kan kom tot die volle som van die geleerdheid. Indien die Christelike universiteit net as funksie het die oordrag van geleerdheid, sou dit gou in sy werksaamhede gaan stilstaan en dan uiteindelik ophou om 'n inrigting vir die geleerdheid te wees. 'n Uiters gewigtige roeping van die geleerde aan die Christelike universiteit is dus om sy deel by te dra tot die uitbouing en ontwikkeling van die wetenskap.

In die derde plek is dit 'n essensiële funksie van die Christelike universiteit om die jeugdige Christelike student nie alleen in te lei in die som van die wetenskaplike kennis nie maar ook om hom te vorm en voor te berei tot selfstandige beoefening van die wetenskappe. 'n Student wat net kom om kennis op te doen, het nog nie sy leerlingskoene ontgroei nie. Aanvanklik is sy taak om hom grondig op die hoogte te bring met die stand van ons wetenskaplike kennis maar uiteindelik word hy ook geroep-en dan bedoel ek veral die meer gbeaafde student-om aan die uitbouing en ontwikkeling van ons kennis mee te doen. Hoogleraar en student word dan commilitones in die ontwikkeling van die Christelike wetenskap.

Maar by ' $n$ blote insameling van kennis en selfs by ' $n$ selfstandige beoefening van die wetenskap mag dit nie bly nie..... Daar is ' $n$ hoër funksie van die Christelike universiteit. Die wese van die universiteit lê, soos ons reeds gesê het, in die filosofiese. Die Christelike universiteit moet deur sy onderrig en sy selfstandige ondersoek die student bring tot 'n wetenskaplike formulering van 'n saamhangende, doeltreffende en gefundeerde lewensfilosofie na die Christelike beginsel. Die onderrig op die universiteit is nie meer bloot empiries en geneties van aard nie, dit is heel in die besonder filosofies. Die wetenskap moet soos dit onderrig en ontwikkel word, verstaan word in die lig van die geopenbaarde waarheid. 'n Christelike universiteit wat nie die kennis en wetenskap verstaan in die lig van die Skriftuur nie, vervul nie sy hoogste funksie nie. 'n Student wat die universiteit verlaat, mag in sy kennis nog ver van volledige ontwikkeling staan, maar hy mag geen twyfel meer hê oor die betekenis daarvan nie: hy moet weet wat die sin en betekenis is van die Christelike wetenskap, d.w.s. van gesistematiseerde kennis gegrond op die Christelike lewens- en wêreldbeskouing. Die boustene van die wetenskap is vir die Christen en die nie-Christen dieselfde, maar die struktuur wat daarmee saamgestel word, verskil al na gelang van die plan. En die bouplan van die Christen verskil in wese van dié van die nie-Christen. Die formulering en uitlewing van 'n Christelike lewens- en wêreldbeskouing deur en op die Christelike universiteit is inderdaad sy hoogste funksie. 
Maar die student kom na die Christelike universiteit vir meer as net onderrig in en beoefening van die wetenskap. Hy verlang ook van sy universiteit vorming en voorbereiding tot die bekleding van maatskaplike betrekkings waarvoor 'n wetenskaplike opleiding vereis word of van groot diens kan wees. 'n Uiters belangrike funksie van die Christelike universiteit is dus die beroepsvorming van die jong Christelike student. Ten opsigte van die vorming en voorbereiding het die Christelike universiteit 'n besonder hoë roeping: dit moet nie alleen voorberei vir die maatskaplike betrekking nie, maar dit moet die jong student laat besef en deurleef dat 'n maatskaplike betrekking nie 'n job is nie maar 'n roeping. Hoër as die beroepsbekwaamheid moet die inrigting stel roepingsbewusthied: elke werk is 'n taak deur God opgelê. Geen ander mens het 'n grondiger besef van professionele opleiding as die Christen nie. Die Christelike geleerde staan teenoor die voorbereiding tot die bekleding van maatskaplike betrekkings in 'n ander opsig ook op 'n besonder hoë standpunt. Die voorbereiding wat hier aan die student verskaf word, is universitêr van aard en nie net tegnies nie. Saam met ander ernstige denkers pleit die Christelike geleerde vir die inskakeling van die tegniese opleiding vir die hoër d.w.s. die meer geleerde, beroepe in die funksies van die universiteit. Professionele opleiding ontaard in blote tegniek aan die sg. suiwer tegniese inrigtings. Dit is alleen op die universiteit waar die professionele opleiding tot 'n wetenskap en 'n prkatyk van die beroep word.

Die vorming en voorbereiding van die student vir 'n toekomstige maatskaplike betrekking bring 'n verdere belangrike funksei van die Christelike universiteit mee. Die student moet as Christen ook gevorm en voorberei word vir volle deelname san die gemeenskapslewe, afgesien van die blote bekleding van 'n betrekking daarin. Die student moet om 'n tipies Amerikaanse woord te gebruik ,gesosialiseer" word. Hy moet gevorm en voorberei word om met sy medemens saam te werk en saam te lewe. Vir die jong Christen beteken dit 'n Christelike vorming ten opsigte van sy sedelike lewe. Vir hom beteken dit iets anders en iets meer as die blote menslike sedelike vorming. Vir hom bestaan die ware sedelike lewe in die gehoorsaamheid aan die eise van Gods wet. Daar is beslissende gemeenskaplike lewenswaardes wat die Christenstudent sy eie moet maak: plig, redelikheid, goeie trou, goeie gesindheid, matigheid, moed, ordelikheid, wetsgehoorsaamheid, veróraagsaamheid, self beheersing, saamhorigheid, vryheid en so meer. Maar daar is nog meer: die goeie Christen is ook 'n goeie landsburger. Die Christen aanvaar die feit dat die Skepper ook die Here van die volke en nasies is. By die opvoeding van sy jeug gee hy ook volle aandag aan die 
burgerlik nasionale vorming. As inrigting vir hoër onderwys wat veral te doen het met die toekomstige volksleiers, aanvaar die Christelike universiteit as een van sy essensiële funksies die Christelik nasionale vorming van sy studente.

c. Die opbou van 'n bepaalde, Christelike lewens- en wêreldbeskouing kan beskou word as die belangrikste taak van 'n Christelike universiteit. Daarom moet by die ondersoek na die funksies van die Christelike universiteit besondere aandag gegee word aan die samestalling van die kurrikulum, want elke vakstudie en die hele verblyf aan die universiteit moet boustowwe lewer vir die formulering en uitbouing van die lewens- en wêreldbeskouing van die studente. Maar 'n Christelike universiteit het ook behoefte aan wat in die universitêre deukwêreld genoem word 'n studium generale.

Die Nederlandse „Staatscommissie” gee in sy rapport oor die reorganisasie van die hoër onderwys besondere aandag aan die saak van 'n studium generale. Dieselfde gedagte word enigsins anders gestel in die Harvardrapport en in die President-rapport, albei uit die Verenigde State. Die wydverspreide wens na 'n studium generale kom voort uit die volgende motiewe: elke wetenskap moet sy plek in die universitas scientiarum verstaan en daarvoor is nodig wysgerige besinning; die verregaande differensiasie by die bestudering van die afsonderlike wetenskappe laat alle eenheid in die studie verlore gaan; daar is sowel by hooglerare as by studente ' $n$ onverantwoorde onwetendheid omtrent die maatskaplike en geestelike kragte wat ons tyd beheers, omdat die bepaalde vakstudies hierdie kennis en insig nie bring nie; daar is 'n gemis aan karaktervormende werking en hulp by die opbou van 'n gegronde, gesistematiseerde lewens- en wêreldbeskouing. Daarom voel die Nederlandse Staatskommissie o.a. dat so ' $\mathrm{n}$ studium generale ten doel moet hê die bevordering van insig in ons kultuurlewe, die bevordering van insig in die samehang van die wetenskappe onderling en begrip omtrent karakter, werkwyse en resultate van die afsonderlike wetenskappe wat die algemene kultuurlewe vorm, en die verdieping van die verantwoordelikheidsbesef van die geleerde mens vir die sosiale, nasionale en kulturele waardes.

Met hierdie standpunt kan ons ons as Christelike geleerdes heeltemal vereenselwig. Vir ons lê die ware krisis in die universiteitslewe juis daarin dat in meeste moderne universiteite alle eenheid gemis word. Daar is geen geformuleerde geestelike grondslag wat die funksies van die universiteit rig en saambind nie. Nou bied die Christelike universiteit juis daardie grondslag aan sy aktiwiteite. Die grondslag is die Christelike religie en 
daaruit voortspruitende die Christelike lewens- en wêreldbeskouing wat aan die wetenskappe 'n eie karakter en aan die universiteit 'n Christelike karakter gee. Christelike religie en filosofie wys aan elke vakwetenskap sy plek in die ry van die wetenskappe aan, bind die wetenskappe saam tot een wêreldbeeld, gee hooglerare en studente wetendheid omtrent die maatskaplike en geestelike kragte wat ons tyd beheers, voorsien die karaktervormende werking en hulp by die opbou van 'n lewens- en wêreldbeskouing. Die Christelike religie en filosofie bevorder die insig in ons kultuurlewe, in die samehang van die wetenskappe onderling en die begrip omtrent karakter, werkwyse en resultate van die afsonderlike wetenskappe, en verdiep die verantwoordelikheidsbesef van die geleerde mens vir die sosiale, nasionale en kulturele waardes.

Om sy taak behoorlik te vervul moet aan die Christelike universiteit beoefen word die artes liberales en die scientiae, moet dit sorg nie alleen vir die breeds moontlike grondslag vir studie nie maar ook vir die beoefening van die vakwetenskappe op grondslag van die voorstudie, en moet dit voorrang verleen aan wat voorrang verdien.

By 'n grondige bestudering van 'n universitêre loopbaan kom die Christelike geleerde tot die gevolgtrekking dat die student ingelei moet word in die grondslae van die vakwetenskaplike studie voor hy begin met die spesialisering. Neem ons 'n oorsig van wat 'n student aan die universiteit nodig het, kom ons tot die konlkusie dat vir hom oop lê minstens ses studieterreine. Die eerste terrein waarvan die student kennis moet hê, is die fisiese skema van die skepping, die tweede die grondverskynsels van die organiese lewe, die derde die verskynsel van die hoistoriese proses, die veirde die verskynsel van die bou en funksie van die menslike samelewing, die vyfde die vraagstuk na die plan van die univers en ten laaste die probleem van die religieuse. Daar is dus minstens ses wetenskaplike terreine: die natuurkundige (fisiese), die biologiese, die historiese, die sosiologiese, die filosofiese en die teologiese wetenskappe. Op die Christelike universiteit neem die Teologie weer sy ereplek in-nie die monopolie soos in die Middeleeue nie, ook nie vereensaamheid, selfs verstotendheid soos in die twintigste eeu nie, maar die sentrum, die bronaar, die kern. 'n Christelike universiteit sonder 'n teologiese fakulteit is ondenkbaar.

Met die oog op die beslissende funksies van die Christelike universiteit soos onder (b) geformuleer, moet elke student daarvan gedurende sy voorgraanse studie minstens een vak uit elk van die ses hoofgroepe kies. Aanvanklike spesialisering kan toegelaat word deur die student vryheid te 
gee om een of meer vakke vir meer as een jaar te neem. As beginsel egter moet gehandhaaf word die eis dat die studie vir die baccalaureusgraad oorwegend algemeen moet wees. Werklike spesialisering, d.w.s. die beoefening van 'n scientia, behoort eers aan te vang met die studie vir die magistersgraad. Dit was die blywende goeie van die middeleeuse universiteit: die artes liberales as grondslag en voorbereiding vir die gekose scientia.

\section{Die Plek van die Christelike Universiteit:}

a. Onder hierdie hoof wil ek 'n kort studie maak van die verhouding van die universiteit tot die owerheid en teenoor ander onderwysinrigtings en die maatskappy in die algemeen en die besonder. Hier sal dit gaan veral oor die selfstandigheid en die af hanklikheid van die universiteit as instelling vir hoër onderwys in die menslike samelewing. Naas die selfstandigheid van die universiteit moet ons ook stel sy verbondenheid aan ander instellings en gemeenskappe. In terme van die Calvinistiese wysbegeerte van die wetsidee gespreek vind ons hier die uitwerking van twee grondbeginsels van ons denke oor die kosmos. Die eerste is die beginsel van die soewereiniteit in eie kring, wat beteken dat die verskillende lewenskringe onherleibaar is, dat elke kring sy eie struktuur en aard het wat tot geen ander herlei kan word nie, dat die wette van elke kring binne die kring geld maar nie daarbuite nie. dat binne sy gebied soewereiniteit, selfstandigheid geld. Die tweede is die beginsel van die universaliteit in eie kring, wat beteken dat die hele tydelike werklikheid in sy volle samehang hom uitdruk binne die grense van elke kring, dat in elke kring die hele kosmos hom weerspieël, m.a.w. dat elke kring 'n klein kosmos op homself is. Die twee beginsels werk saam sodat selfstandigheid en soewereiniteit altyd gesien moet word in afhanklikheid, en universaliteit. Elke kring in die menslike samelweing is, nieteenstaande sy soewereiniteit, vervleg met elke ander kring. Daar is dus onderlinge verhouding, wisselwerking, vervlegting.

In juridiese taal gespreek, is elke individu, elke instelling, elke gemeenskap soewerein en onderdaan tegeluk. Die universiteit as maatskaplike instelling en as 'n klein gemeenskap van mense is dus sowel selfstandig as onderworpe. Nóg die selfstandigheid, nóg die onderworpenheid is absoluut; albei is relatief. Met die grondgedagte kan ons nou oorgaan tot die ondersoek van die verhoudingsvraagstuk.

b. In 'n moderne goed georganiseerde staat onderskei ons onmiddellik tussen 'n owerheid ('n klein minderheid) en sy onderdane (die oorgrote meerderheid). Owerheid en onderdane is saam verbind in 'n staat. Die 
staat is dus ' $n$ instelling in die menslike samelewing waarvan die hooffunksie is die ordening van die volksgemeenskap. In die staat het die owerheid seggenskap oor die onderdane, omdat dit die mag en gesag besit. As owerheid is dit geroepe om te sorg vir die handhawing van sy gesag maar ook vir die uitoefening van die reg. Dit lê die wette neer, dit interpreteer en dit handhaaf hulle, en dit alleen ter wille van die bestaan, voortbestaan en ontwikkeling van die menslike samelewing. Die onderdaan is gehoorsaamheid verskuldig aan sy owerheid, waarsonder die volksbestaan onmoontlik is. Maar net soos die owerheid gesag en reg moet handhaaf--dus mag en plig het-, net so moet die onderdaan gehoorsaamheid betoon en reg besit. 'n Onderdaan sonder regte is slegs te vind in diktatoriale lande; onder 'n demokratiese staatstelsel het onderdaan regte sowel as pligte. Die regte van die onderdaan bestaan hoofsaaklik in private besit, persoonlike oortuiging, sedelike normering van die wil, ontwikkeling van die eie persoonlikheid. Solank die owerheid handel ooreenkomstig die ewige regsbeginsels, moet die onderdaan hom gehoorsaam; as dit nie so handel nie, tree die reg en vryheid van die onderdaan na vore.

In 'n staat staan die onderdaan dus onder die owerheid. Die staat is dus eintlik die organisasievorm van die reg in die volkslewe. Elke kring, instelling, gemeenskap in die volkslewe is onderhewig aan die gesag in die staat maar besit ook sy eie reg. Soewereiniteit in eie kring moet aangevul word deur universaliteit in eie kring.

Die universiteit is self ' $n$ instelling, 'n gemeenskap in die volkslewe en is dus inbegryp in die staat. Dit is geen staatsowerheid nie maar 'n staatsonderdaan. Van absolute soewereiniteit of outonomie van die universiteit kan daar dus geen sprake wees nie, net so min as van die absolute soewereiniteit van die owerheid oor die universiteit. Staatsuniversiteite moet dus in beginsel verwerp word, net soos ons die sg. outonome universiteit ook moet verwerp. Ons beginsel stel die bestaan van staatsondersteunde universiteite as die ideaal.

Ten aansien van die onderwys lê dit op die weg van die staat om te sorg vir die beveiliging en handhawing van die volkseenheid, vir die besieling van die opkomende geslag met die heroïke gees van die vaderlandse verlede, vir die handhawing van die eenheid en selfstandigheid van die landstaal (-le) in alle landsdele, maar veral vir die handhawing van 'n behoorlike peil van algemene volksontwikkeling, vir die handhawing van reg en geregtigheid op onderwysgebied. Maar die staat beskik nie oor die reg om te beslis oor die beginsel, die gees en rigting van die onderwys en opvoeding, solank 
dit nie sedebederwend of staatsvernietigend is nie. Aan alle sedebewarende en staatsbevorderdende onderwysinrigtings moet dit sy steun gee.

Tot aan die begin van hierdie eeu was staatsbemoeiing met die hoër onderwys betreklik beperk. Dit spreek vanself dat die staat sy eerste aandag sou gee aan die laer en later aan die middelbare onderwys. Dit het reeds in die negentiende eeu begin om verpligte laer onderwys in te voer en aan die begin van hierdie eeu gevolg met die verskaffing van gratis onderwys. Dit het geleidelik die peil van verpligte-en van gratis-onderwys verhoog, sodat dit in Suid-Afrika alreeds gekom het tot die bepaling van die agste standerd. Die middelbare onderwys tot standerd 10 is reeds in byna alle beskaafde lande geldvry. In feite is alle laer en middelbare onderwys suiwer staatsonderwys: die staat stig die skole, onderhou hulle geheel en al en beheer hulle feitlik heeltemal. Skoolkommissies en beherende liggame het wesentlik min te sê. By die hoër onderwys het staatsbemoeiing 'n ander karakter aangeneem. Die owerheid-in die Middeleeue kerklik, sinds die Renaissance al meer en meer wêreldlik-het óf net 'n grondwet vir die universiteit vir sy stigting goedgekeur of een of ander visitatoriale mag oor die inrigting uitgeoefen óf hoogstens net die hoofamptenare van die universiteite aangestel. Maar in die loop van die moderne eeue het dit al meer en meer direkte aandag aan die universiteite gaan gee. In sekere lande het dit selfs universiteite gestig, soos o.a. die bekende Ryksuniversiteite in Nederland van die negentiende eeu. Waar die owerheid stig, daar finansier en beheer dit die inrigting heeltemal. Waar universiteite onafhanklik van die staat gestig is, het die staat behalwe wetlike erkenning ook begin om hulle finansieel te ondersteun. Die finansiële ondersteuning het met die jare al meer en meer toegeneem-en met die toenemende finansiële steun het ook gekom toenemende beheer en dus ' $n$ bedreiging van die selfstandigheid van die inrigtings. Die beheer beperk hom egter hoofsaaklik tot die geldelike administrasie van die universiteite. As inrigtings het hulle veral ten opsigte van die akademiese sy hul vryheid goed behou. Die universiteit moet sy regte behou ten aansien van die onderrig, die beoefening en die ontwikkeling van die wetenskap self maar ook gedeeltelik ten opsigte van sy interne administrasie en organisasie. Die beste resultate in onderwys en navorsing word dán alleen verseker as die beheer daarvan oorgelaat word aan deskundiges. Universitêre selfstandigheid vorm ' $n$ inherente deel van die Westerse tradisie van spontane ontwikkeling. Redelike selfstandigheid verseker dat die universiteit sy hoogste taak vervul, nl. die ontwikkeling van die wetenskap deur selfstandige navorsing en skeppende deurdenking. Sonder enige staatsbeheer kan die universiteit so maklik ontaard in 'n ge- 
stereotiepte gilde wat in homself genoegsaam voel en waar die „skeppende” langsamerhand moet onderdoen vir die bloot „kritiese”. Sonder die nodige die nodige staatsbeheer kan die universiteit in 'n al erger wordende vereensaamheid beland. Maar alle staatsbemoeiing bring met hom mee die dodelike gevaar van politieke inmenging. Daarenteen is 'n mate van staatsbemoeiing absoluut essensieel ten opsigte van universitêre hervorming. Uit hulleself sal die universitêre inrigtings nie snel en doeltreffend genoeg hervorm nie. 'n Sprekende voorbeeld van die aansporing tot dade is die uitwerking van die verslag van die Universiteitskommissie van 1928 op die groei en ontwikkeling van die Potchefstroomse inrigting. Die owerheid moet toesien dat daar op universitêre gebied beplan word, en ons eeu van krisis eis juis deeglike beplanning. Maar die werklike waarborg vir universitêre hervorming kan tog weer nie die wet en die owerheid wees nie: die waarborg daartoe moet van binne kom, nl. die drang na ware geleerdheid, die innerlike begeerte na wetenskaplike deurvorsing. Daarom moet die universiteit die nodige en genoegsame selfstandigheid besit maar daarby ook die doeltreffendste inwendige rekbaarheid en veral 'n diepgevoelde verantwoordelikheidsbesef. Daar hoef dus geen stryd te wees tussen staat en universiteit nie: hul juiste verhouding is nie die van heer en dienskneg of van werker en gereedskap of van werkgewer en werknemer of van superieure en inferieure nie maar eerder die van konsument en produsent, van klient en handelaar.

In 'n Christelike land vind 'n Christelike universiteit vanselfsprekend 'n tuiste, soos in die geval van die Potchefstroomse inrigting. Deur wetgewing word dit van owerheidsweë gevestig. In daardie wetgewing word sy gees en rigting erken en gewettig. Daarmee word nie gesê dat dit 'n beter inrigting is as die andere nie. Dit word alleen bepaal dat sy eie karakter Christelik sal wees. Maar selfs in 'n nie-Christelike land het dit 'n reg van bestaan, mits daar in die land 'n aansienlike aantal Christene deel uitmaak van die volksgemeenskap. Die staat is wel 'n eenheid maar die volksgemeenskap 'n verskeidenheid, en die owerheid is geroepe om erkenning te verleen aan die verskeidenheid en daaraan die reg te laat geskied. Daar kan dus universiteite wees met verskillende geestelike grondslae, en 'n universiteit met ' $n$ Christelike grondslag maar sy voortbestaan is alleen moontlik as die owerheid sy Christelike grondslag wettig.

c. Teenoor ander onderwysinstellings het die universiteit ook sy besondere roeping en verantwoordelikheid.

Die universiteit self is die hoogste sport in die opvoedkundige trappeleer. 
Die hele onderwysstelsel loop daarin uit. Omdat dit die kroon van die onderwys is, het die universiteit groot verantwoordelikheid teenoor die skole, en heel in die besonder teenoor die middelbare skool wat dien as die deurgang na die universiteit self. Die universiteit moet sy eie plek in die stelsel goed deurdink. Sonder die primêre en die sekondêre onderwys is die tertiêre onderwys ondenkbaar. Maar daarmee mag nie gesê word dat die hoër onderwys die laer en die middelbare moet bepaal nie. 'n Universiteit wat aan die middelbare skool voorskryf, oortree die beginsel van soewereiniteit in eie kring. Die middelbare skool is 'n eie kring en dit moet selfstandig sy eie doel, aard, karakter, inhoud en metode bepaal. Die roeping van die universiteit is in die eerste plek om aan te sluit by die onderwys van die middelbare skool. Maar omdat dit 'n akademie is vir die beoefening en ontwikkeling van die wetenskap, moet dit wel die middelbare skool adviseer aangaande nuwe ontwikkelinge op die gebied van die vakwetenskappe. Die belangrikste invloed van die universiteit op die gewone skole lê egter in een van sy belangrikste funksies, nl. die vorming en voorbereiding van sy studente vir opvoedkundige betrekkings, m.a.w. die opleiding van onderwysers vir die skole. Onderwysersopleiding is ' $n$ inherente deel van die funksie van die universiteit. Aan die universiteit word die aanstaande onderwyser opgelei nie alleen in die moderne teorie en praktyk van die opvoeding nie maar ook in die moderne vakwetenskpalike kennis en beoefening daarvan. Verdere kontak met die gewone skole moet gesoek word in die onderlinge geleerde verkeer tussen hooglerare en onderwysers: van mekaar kan veel geleer word. En om nie meer te noem nie-dit lê op die weg van hooglerare om diens te doen op skoolkommissies, beheernde liggame en skoolrade.

Ten aansien van ander universiteite het elke universiteit besondere verpligtings. Die hoër onderwys in 'n land is die gesamentlike taak van sy verskillende universiteite. Omdat dit 'n gesamentlike taak is, moet die universiteite 'n verhouding van samewerking, en nie van bekamping of teenwerking nie as grondslag van alle aktiwiteit neerlê. Die een universiteit is nie daar om met 'n ander te kompeteer nie: elkeen is daar om sy bepaalde deel van die gesamentlike taak uit te voer. Die een is nie beter of hoër as die ander nie: elkeen is daar vir die beste diens aan sy land. Saamwerk vereis verdeling van arbeid en bepaling van elkeen se taak en plek. Om die samewerking doeltreffend en ekonomies te maak moet daar 'n liggaam wees wat die samewerking kan beplan. Dit sal so 'n soort van adviserende interuniversitêre raad moet wees. Dit moet interuniversitêr wees in die sin dat alle universiteite op die raad gelyke verteenwoordiging sal hê. Dit moet adviserend wees in die sin dat dit in geen enkele opsig die selfstandigheid 
van die indiwiduele universiteite sal aantas nie: dit gee geen bevele nie, dit gee slegs raad. Die werksaamhede van die Adviserende Raad sal insluit o.a. vraagstukke in verband met die uitruiling van studente, met owerheidstoelae per student, met die sosiale sorg en nasorg van die studentebevolking, met die studium generale, met gesamentlike navorsing op 'n volksbreë basis, met proefnemings en gedagtes oor metodes van onderrig en navorsing, van organisasie en administrasie.

d. Die universiteit kom ook te staan teenoor die volkslewe in sy geheel en in sy verskillende geledinge.

In sy rapport oor die reorganisasie van die Nederlandse hoër onderwys stel daardie Staatskommissie die verhouding van die universiteit teenoor die maatskappy besonder mooi. Die universiteite, beklemtoon die kommissie, vorm waardevolle elemente van die samelewing. Die universiteit is bedoel as 'n sentrum van wetenskaplike lewe, waar die wetenskap beoefen en aan ' $n$ volgende geslag oorgedra word. Die maatskaplike waarde van die universiteit is van drieërlei aard, dit is die draer van die wetenskaplike element in die kulturele lewe; dit voorsien die maatskappy van wetenskaplike gevormde kragte wat dit as predikante, geneeshere, regters, onderwysers, leiers op industriële en kommersiële gebied nodig het; dit is ' $n$ vormende krag op geestelike en sedelike gebied. Daarom moet die universiteit rekening hou met die maatskappy wanneer dit o.a. besig is met die samestelling van die studieprogrammas: die maatskappy het sy eise nie alleen ten opsigte van die algemene wetenskaplike vorming nie maar ook ten aansien van die inhoud en omvang van die studie en van die aard en vorm van die voorbereiding van die studente vir die maatskaplike betrekkings. Die universiteit moet rekening hou met die hele arbeids- en bedryfslewe van die volksgemeenskap. En dit moet van sy kant alle pogings aanwend om die bedryfslewe en ander maatskaplike organe in die universiteit geïnteresseer te kry. Materieel en formeel moet die maatskaplike organe tot die universitêre lewe bydra. Een van die beste bronne van inkomste vir die universiteit is juis die groot kapitaal, en een van die beste plekke van belegging van die groot kapitaal is juis die fondse van die universiteit. As staatsondersteunde inrigtings moet die universiteite bronne van private inkome ook hê. Om sy groot en onmisbare dienste aan die volksgemeenskap in sy geheel moet die universiteite deur die volksgemeenskap gesteun word. Die universiteit moet vir die volkslewe opvoed en voorberei. Maar dit moet meer as net vorm en voorberei vir die arbeids- en bedryfslewe van die maatskappy. Dit moet ook vorm en voorberei vir die staatslewe as sodanig. Die universiteit is 
ook ' $n$ brandpunt van staatkundige denke en 'n prikkel tot staatkundige aksie. Dit moet dus ook 'n opleidingsplek wees vir die politiek in die beste sin van die woord. Dit moet egter waak teen die aktiewe deelname aan die sg. party-politiek: dit is geen propagandis vir een of ander party-politieke rigting nie, dit is ' $n$ akademie waarop die vraagstukke van die landspolitiek op 'n wetenskaplike, rustige en prinsipiële wyse bestudeer word.

Maar die universiteit het teenoor die volk en land in geheel ook nog 'n ander belangrike roeping. Dit moet ook sorg dra vir die behoud en oordrag van die nasionale kultuur; dit moet dus voorsiening maak vir die onderrig en leiding ten opsigte van die belangrikste aspekte van die nasionale kultuur. Elke universiteit moet 'n nasionale karakter dra en elke Christelike universiteit 'n Christelik nasionale karakter.

Die Christelike universiteit moet in die volkslewe 'n sentrum van Christelike wetenskaplike lewe wees waar die wetenskap op Christelike grondslag beoefen en aan die volgende geslag oorgedra word. Dit is die draer van die Christelik wetenskaplike element in die kulturele lewe; dit voorsien die maatskappy van Christelik wetenskaplike gevormde kragte soos predikante, onderwysers, geneeshere, regters, industriële en kommersiële leiers; dit is 'n vormende krag op Christelik geestelike en sedelike gebied. Die Christelike universiteit moet hom in die besonder wend tot die Christelike element in die maatskappy - die element interesseer in die Christelike hoër onderwys -en van hulle die nodige steun inwag.

Maar elke universiteit het ook 'n meer plaaslike gemeenskap en omgewing waarin hy geplaas is en waaruit hy studente en steun ontvang. Tussen „gown" en „town" moet daar die innigste verhouding bestaan: „gown" en "town" moet onderling in mekaar belangstel en wedersyds mekaar steun. Die universiteit mag hom nie afsydig hou van sy lokale omgewing nie. Hy het dit nodig vir direkte kontak met die maatskaplike lewe. Vir die lokale omgewing is die universiteit nie alleen op industriële en kommersiële gebied 'n bron van waarde nie maar ook op intellektuele en kunsgebied 'n leier en voorganger. Maar die universiteit moet breër lewe as net in en vir die lokale gemeenskap. Daarom moet dit geen aandeel hê in die klein gedoe van plaaslike liggame nie. Vir sy werk is alle parogialisme en filistynisme dodelik. Dit moet alle pogings aanwend om veral sy studentebevolking uit 'n breër gebied as net die lokale omgewing te trek. In sy diepste wese moet hy ,universitas" bly: van heinde en ver sowel as van naby moet die studerendes getrek word. In die besonder moet die universiteit in sy beheerliggame genoeg lokale manne betrek, manne van insig, wetenskapli ke vorming 
en invloed. Vanuit die "local habitation" moet die krag en roem van die universiteit deur die breedte en lengte van die vaderland versprei. Die Potchefstroomse Universiteit vir Christelike Hoër Onderwys moet die Christelike gemeenskap sowel in Potchefstroom en Wes-Transvaal as in die hele Unie van Suid-Afrika dien en deur hulle gedra word. Daarmee wil dit nie te kenne gee dat ander Suid-Afrikaanse universiteite nie ook in hul onderrig en wetenskapsbeoefening Christelik is nie, maar alleen dat dit ooreenkomstig sy oktrooi die reg het om homself te beskou as 'n inrigting vir Christelike hoër onderwys. Dit is sinds 1919 nie meer 'n kerklike inrigting nie maar reeds vanaf sy inkorporsaie in 1921 en veral vanaf die herverkryging van sy volledige naam in 1934 en heel besonderlik vanaf sy selfstandigwording in 1951 'n staatsondersteunde openbare inrigting vir Christelike hoër onderwys: emige student mag hier studeer maar hy weet presies wat hy sal kry: Christelike hoër onderwys.

\section{Bibliografie:}

\section{A. Boeke:}

Anema, A. e.a.: Christendom en Opvoeding. Hollandia Baarn. s.j.

: Vrije Universiteit en Cultuurcrisis. Vada, Wageningen, 1935.

Boyd, W.: History of Western Education. Black, London. 1928

Bradby, E.: The University outside Europe. Oxford University Press. 1939.

Brownell, B.: The College and the Community. Harper, New York. 1952.

Butler, N. M.: Scholarship and Service. Scribner, New York. 1921.

Galvin College and Seminary： „The Calvin Forum" en ander uitgawes oor en deur.

Carmichael, 0 . C.: The changing role of higher Education. Macmillan, New York 1949.

Christelijke Encyclopaedie: $6 \mathrm{dln}$. Kok, Kampen. 1925-31.

Cilliers, A. C.: The State and the Universiteis. Miller, Cape Town. 1944.

Clarke, F.: Education and Social Changes. Sheldon Press, London. 1940.
Coetzee, J. Chr. en Van Rooy, D. J.: Beginsels en metodes van die hoër onderwys. Van Schaik, Pretoria. 1949.

Collins, L. J.: A Theology of Christian Action. Hodder and Stoughton, London 1949.

Commonwealth Universities Congress Reports.

Deferrari, R. J. ed.: Integration in Catholic Colleges and Universities. Cath. Univ. America, Washington.

Deller, E.: Tendencies in University Education. Oxford Univ. Press. 1933.

De Ru, C.: Strijd om Hoger OnderwijsKuyper. Kok, Kampen. 1953.

Eliot, T.S.: The idea of a Christian Society. Faber and Faber, London. 1948.

Emmet, D. H.: The Foundation of a free University. S.C.M. Press, London. 1946.

Fairchild, H. P.: The obligation of the Universities to the social order. New York Univ. Press. 1933.

Flescner, A.: Universities, American, English and German. Oxford Univ. Press. 1930. 
Geesink, W.: De Dogmatische Grondslag der Vrije Universiteit te Amsterdam. Höveker en Wormser, Amsterdam. 1904.

Germany, Commission University Reform, Report. H.M.S.O., London. 1949.

Gideonse, H. D.: The higher learning in a democracy. Farrar and Rhinehart, New York. 1937.

Grierson, H.: University and liberal Education. Oliver, Edinburgh.

Hartshorne, E. Y.: The German Universities and National Socialism. Cambridge Univ. Press. 1937.

Harvard Committee: Report on General Education in a free Society. Harvard Univ. Press. 1946.

Hasen Foundation: College Reading and Religion. Yale Univ. Press. 1948.

Hodges, H. A.: The Christian in the modern Lniversity. S.C.M. Press, London. 1946.

Hodgson, J. G.: Trends in University Education. Wilson, New York. 1931.

Holme, E. R.: American University. Angus. Sydney. 1920.

Hugo, T. J.: Die Afrikaanse Universiteit en sy taak in die Volkslewe. Nasionale Pers, Bloemfontein. 1941.

Hutchins, R. M.: Higher Learning in America. Yale Univ. Press. 1936.

: No Friendly Voice. Chicago Univ. Press. 1936.

Jacks, M. L.: Total Education. K. Paul, London. 1946.

Janse, A.: Het eigen karakter der Christelijke school. Kok, Kampen. 1935.

Jenkins, D. T.: Place of a Faculty of Theology. S.C.M. Press, Lonson. 1946

Jefiery, G. B.: The Unity of Knowledge. Cambridge Univ. Press. 1950.

Jeffreys, M. V. C.: Education, Christian and pagan. Univ. London Press. 1946. : Glaucon. Isaac Pitman, London. 1950
Kamp, J.: Volksleven en hoger onderwijs. Het Westen, Potchefstroom. s.j.

Knothe, G.: Kijkjes in de Geschiedenis van ons Hoger Onderwijs. Het Westen, Potchefstroom. 1913.

Knotschnig, W. B. and Prys, S.: The Lniversity in a changing norld. Oxford Univ. Press. 1932.

Kristelike Unie: Etlike brosjures oor hoer onderwys. P.U.K., Potchefstroom.

Kruyt, H. R.: Hoge School en Maatschappy. Paris, Amsterdam. 1946.

Kuyper, A.: Ons Program. Höveker en Wormser, Amsterdam. 1907.

Laurie, S. S.: The rise and early constitution of Universities. K. Paul, London. 1886.

Leavis, F. R.: Education and the University . Chat to and Windus, London. 1943.

Leeson, S.: Christian Education. Longmans, Green and Co., London. 1947.

Lilge, F.: Absence of Learning-failure of German Universities. Mcamillan, New York. 1948.

Livingstone, R.: Some thoughts on University education. National Book League London. 1948.

Lowe, A.: The Universiteis in Transition. Sheldon Press, London. 1940.

Metrowich, F. C.: The development of higher education in South Africa, 1873. 1927. Miller, Cape Town. 1929.

Moberly, W.: The Crisis in the University. S.C.M. Press, London. 1949.

Monroe, P.: Cyclopaedia of Education, 5 Vols. Macmillan, New York.

Nash, A. S.: The University and the modern world. Macmillan, New York. 1944.

Nederland: Rapport van de Staatscommissie tot reorganisatie van het hoger onderwijs. De Staatsdrukkerij, 's Gravenhage, Nederland. 1949. 
Newman, J. H.: The idea of a university. Dent, London. 1939.

N.U.S.A.S.: The Concept of a University, University of Cape Town. 1953.

Orelga, Y. Ganet, J.: Mission of the University. K. Paul, London. 1946.

Paton. D. H.: Religion in the Universities. S.C.M. Press, London. 1946.

Paulsen, F.: Gerschichte des gelehrten Unterrichts. Veit, Leipzig. 1919-21.

Postma, F.: Verspreide bydraes oor hoër onderwys in P.U.K. publikasies.

President's Commission on Higher Education: Higher Education for American Democracy. A Report. Harper Bros. New York. 1947.

P.U.K. vir C.H.O.: „Koers"; „Veteraan” en ander uitgawes oor en deur.

Rashdall, H.: Universities of Europe in the Middle Ages. Oxford Univ. Press. 1895.

Reyburn. H. A.: The University and University Education. University of Cape Town. 1934

Romborts, S.: Historiese Pedagogiek. 4 DIn. Jongensweeshuis, Tilburg. 1927e. d.

Romein. J. M.: Universiteit en Maatschappij. Brill, Leiden. 1947.

Schairer, R. und Hoffmann, C.: Die Universitătsideole der Kulturvoikeres. Quelle u. Meyer, Leipzig. 1925.

Schlipp, P. A.: Higher Education faces the future. Liveright, New York. 1930.

Stoddard, G. B. A. O.: Ferment in Education. Univ. Illinois Press. 1948.

Stoker, H. G.: Verspreide bydraes oor hoêr onderwys, veral in "The Critic", "Koers", „Koers die in Krisis", "Die Kcrkblad", "Die Veteraan".
Tead, O.: College teaching and learning Yale Univ. Press. 1950

Tillyard, A. J.: History of University Reform from 1800 A.D. to present time. Heffer, Cambridge. 1913.

Truscott, Bruce: Red Brick University (1943); Red Brick and these vital days (1945). Faber and Faber, London.

Universities of the Empire, Yearbooks.

Vidler, A. R.: Christianity's Need for a free University. S.C.M. Press, London. 1946

Vollenhoven, D. H. Th.: De Noodzakelijkheid eener Christelijke Logica. Paris, Amsterdam. 1932.

Vrije Universiteit, Amsterdam: publikasies oor en deur.

Waterink, J.: Inleiding tot de Theoretische Paedogogiek. Ruys, Zeist. 1926.

Welch, H., King, H.C. and Nicholson, T. : The Christian College. Methodist Book Concern, New York. 1916.

Wending, January, 1951 : Universiteit.

Woltzer, J.: Wat is het doel van het C.N.S. onderwijs? Wolters, Groningen. 1911.

B. Tydskrifte :

Free University Quarterly, De Vrije Universiteit, Amsterdam.

Journal of Higher Education. Ohio State University.

Lniversities Quarteriy. Turnstile Press, London.

Universities Review, Association of University Teachers, Bristol University. 